\title{
Root Diseases of Wheat and Barley During the Transition from Conventional Tillage to Direct Seeding
}

\author{
K. L. Schroeder and T. C. Paulitz, USDA-ARS Root Disease and Biological Control Unit, Washington State Uni- \\ versity, Pullman 99164-6430
}

\begin{abstract}
Schroeder, K. L., and Paulitz, T. C. 2006. Root diseases of wheat and barley during the transition from conventional tillage to direct seeding. Plant Dis. 90:1247-1253.

The use of direct seeding (no-till) in place of tillage can reduce soil erosion and improve water infiltration. However, despite these improvements in soil quality, growers in the Pacific Northwest are reluctant to adopt direct seeding, partially because of fears of increased root diseases caused by Gaeumannomyces graminis var. tritici, Rhizoctonia spp., and Pythium spp. To examine the effect of the transition from conventional tillage to direct seeding, field plots were established at two locations. One site had been managed with direct seeding for 12 years, and the second had been conventionally tilled. Over 4 years, a portion of each plot was tilled or direct seeded, and planted to wheat or barley. Plants in the tilled plots had consistently more crown roots than plants in direct-seeded plots. Rhizoctonia root rot and yield did not differ between tillage types during the first 2 years of the study. However, in the third and fourth years of the transition to direct seeding, a higher incidence of Rhizoctonia root rot, increased hyphal activity of $R$. solani, and reduced yields were observed in direct-seeded plots. Populations of $R$. oryzae and Pythium spp., and incidence of take-all were the same for both management practices.
\end{abstract}

Wheat and barley are well suited for production in the Palouse region of eastern Washington and northern Idaho because environmental conditions and soil quality are conducive for growing cool-season grasses. The traditional method of preparing the seed bed in this region involves significant tillage, but tillage can have serious long-term negative effects on the soil. The steep terrain of the Palouse makes the soil prone to severe erosion by water, and tilled ground is easily eroded by wind. Erosion leads to the loss of topsoil and eventually to reduced yield potential of the land. In the 1970s, an effort was made to introduce direct seeding (notill) into the region. Direct seeding involves planting into the previous year's stubble without seedbed tillage. Unfortunately, the proper tools were not in place to manage root diseases and weeds under this new soil management system. As a result, poor yields were obtained and many growers subsequently abandoned the practice. In recent years, environmental concerns, economic pressures, and increased awareness of the need to conserve and improve the quality of topsoil

Corresponding author: T. C. Paulitz

E-mail: paulitz@wsu.edu

Accepted for publication 2 May 2006.

DOI: $10.1094 /$ PD-90-1247

This article is in the public domain and not copyrightable. It may be freely reprinted with customary crediting of the source. The American Phytopathological Society, 2006. have created a renewed interest in direct seeding.

The effect of direct seeding, compared with tillage, on root diseases of wheat and barley still is not completely understood. Several fungal root diseases can reduce the health and yield of wheat and barley grown in the Pacific Northwest (PNW). These diseases include take-all (Gaeumannomyces graminis (Sacc.) Arx \& D. Olivier var. tritici J. Walker), Rhizoctonia root rot (Rhizoctonia solani Kühn and R. oryzae Ryker \& Gooch), and Pythium root rot (Pythium Pringsh. spp.). Many studies have examined the impact of these diseases on wheat and barley grown with tillage, but few have focused on the effects of direct seeding, and some of these have yielded conflicting conclusions. For example, the incidence and severity of take-all was shown to decrease in some studies $(2,3,22)$ and to increase in others (19) when crops were direct seeded. In a comparison of fields managed by tillage or direct seeding in eastern Washington, the amount of take-all did not differ (25). In another study in Australia, the incidence of take-all increased with direct seeding in two experiments, but not in a third (27). Data suggest that consistently higher levels of Rhizoctonia root rot of wheat are associated with direct seeding $(17,24,28,35)$. More Rhizoctonia root rot also was observed for direct-seeded barley (33). In contrast, in a more recent study conducted in Washington, the severity of Rhizoctonia did not differ between conventionally tilled and direct-seeded plots following several years of direct seeding (29). Higher popu- lation densities of Pythium spp. were detected in direct-seeded plots compared with tilled plots $(5,21)$. However, Smiley and Wilkins (33) showed that the incidence of Pythium root rot did not differ between tilled and direct-seeded plots.

Various factors have been implicated in increased root diseases of wheat and barley grown with direct seeding, including increased organic matter and plant debris serving as a food base for saprophytic survival between growing seasons $(20,21)$, decreased soil temperatures due to residue cover (1), and increased soil moisture (8). However, changes in the organic matter content and increased soil moisture associated with direct seeding also favor the growth of many other microorganisms in the surface layer of soil $(0$ to $10 \mathrm{~cm})(11-$ 13). Thus, the potential exists for a higher general suppression of pathogens in directseeded soils.

The purpose of this study was to reexamine the impact of direct seeding on the incidence and severity of root diseases in cereal crops in eastern Washington, during both the transition from conventional tillage to direct seeding and the conversion from long-term direct seeding to tillage. The objectives were to evaluate root diseases on wheat and barley during the transition, and to estimate populations of $P y$ thium spp. and hyphal activity of Rhizoctonia spp. in each of the two management systems. Replicated field trials were established in direct-seeded and conventionally tilled fields, each with a long history of the respective soil management. At each location, portions of the field were converted to the opposite type of tillage in order to compare the effects of direct seeding both during the early years and later in the transition.

\section{MATERIALS AND METHODS}

Field plots. Plots were established north of Garfield, WA, in 2001 to examine the impact of root diseases under different management regimes. The area is characterized by a climate with cool, wet winters and dry summers with an average of 500 to $600 \mathrm{~mm}$ of precipitation occurring between November and April. Two sites, approximately $2 \mathrm{~km}$ apart, were selected for study. The first, designated the Nelson farm (Thatuna silt loam), was managed with conventional tillage and had no documented history of direct seeding. The second location, designated the Pennell farm 
(Palouse silt loam), was direct seeded for 12 years prior to initiating this study. At each location, one portion of the site was maintained using the previous soil management practices and another portion was converted to the opposite type of management. The Nelson farm was included in the study from 2001 to 2004. However, the Pennell farm plot was discontinued after the 2002 growing season due to a break in a drain tile, which caused flooding throughout the spring and early summer of 2003. At each site, tillage was accomplished by one pass with a John Deere 4200 three-bottom moldboard plow to a depth of about $20 \mathrm{~cm}$ followed by three passes with a three-bar spring-tooth harrow with attached spike-tooth harrow. Tilled and direct-seeded portions of the sites were seeded with a planter equipped with flutedYetter coulters for liquid fertilizer application followed by double disk openers to place the seed about 1 to $2 \mathrm{~cm}$ deep and about 3.5 to $4 \mathrm{~cm}$ above the fertilizer. Soils were collected from each plot prior to planting, and fertility tests were conducted by the Northwest Agricultural Consultants (Kennewick, WA). Liquid fertilizer was applied based on fertilizer recommendations to achieve a spring wheat yield goal of 5.7 metric tons/ha. A 2-year rotation was established at each location using spring wheat (cv. Wawawai in 2001, 2002, and 2004, and cv. Wakanz in 2003) seeded at $114 \mathrm{~kg} / \mathrm{ha}$ and spring barley (cv. Baronesse) seeded at $85 \mathrm{~kg} / \mathrm{ha}$.

Experimental design and plot management. The experimental design at each location consisted of four combinations of variables (spring wheat or spring barley, with or without tillage) replicated eight times in a randomized block design, with each plot measuring $2.4 \mathrm{~m}$ (eight rows) wide by $14.6 \mathrm{~m}$ long. The plots were seeded as soon as spring conditions allowed; however, adverse weather delayed seeding in 2002 and 2003. Plots were planted on 26 April in 2001, 16 May for the Pennell farm and 24 May for the Nelson farm in 2002, 22 May in 2003, and 30 April in 2004. Plots were sprayed within 1 week prior to planting with glyphosate (Glyphomax, Dow AgroScience, Indianapolis, IN) at 1.75 liters/ha. After planting, weeds were managed with tralkoxydim (Achieve, Syngenta Crop Protection, Greensboro, NC) at $0.68 \mathrm{~kg} / \mathrm{ha}$, octanoic acid ester of bromoxynil (Buctril, Bayer CropScience, Research Triangle Park, NC) at 1.75 liters/ha, and trifensulfuronmethyl/tribenuron-methyl (Harmony Extra, DuPont, Wilmington, DE) at $27.9 \mathrm{~g} / \mathrm{ha}$.

Agronomic measurements and disease evaluation. Plant samples were collected twice during the growing season, at tillering (about 4 weeks after planting) and during early heading (about 4 weeks later). At each time, five plants were selected randomly from two sites within each plot. For the first sample, plants were evaluated for number of tillers, number of crown roots, and number of crown roots with symptoms of Rhizoctonia root rot as assessed by visual observation of root lesions. Typical symptoms of Rhizoctonia root rot included browning of root tips in association with cortical constrictions or "spear" shaped root tips. During the second sampling, the number of roots infected with $G$. graminis var. tritici was assessed using a 0 -to-5 disease rating scale $(0=$ healthy root system, $1=$ up to $25 \%$ of roots infected, $2=25$ to $50 \%$ of roots infected, $3=50$ to $75 \%$ of roots infected, $4=$ 75 to $100 \%$ of roots infected, $5=100 \%$ of roots infected and lesions on lower stem) (19) in 2001, and in 2002 to 2004, disease incidence was recorded instead of disease rating because of low disease incidence. At the end of the growing season, plots were harvested by using a Wintersteiger plot combine to obtain yield data.

Evaluation of Pythium populations and Rhizoctonia hyphal activity. Populations of Pythium spp. were estimated from soil samples in 2001 and 2002. Soils samples were removed from each plot at both times of sampling for root diseases in 2001 and at the first sampling time in 2002. Ten grams of soil were combined with $100 \mathrm{ml}$ of sterile water and mixed for $20 \mathrm{~min}$ at $120 \mathrm{rpm}$. The soil slurry was serially diluted and plated in duplicate onto a modified Pythium-selective medium (18) using $2 \%$ water agar rather than cornmeal agar (PSM; 2\% water agar with $100 \mu \mathrm{g} / \mathrm{ml}$ PCNB, $0.25 \mu \mathrm{l} / \mathrm{ml}$ pimaricin, $10 \mu \mathrm{g} / \mathrm{ml}$ rose bengal, and $50 \mu \mathrm{g} / \mathrm{ml}$ rifampicin). Plates were incubated for $48 \mathrm{~h}$ in the dark prior to washing the soil from the surface of the plate to observe colonies. Colonies were counted to obtain the number of viable Pythium propagules per gram of dried soil. The dried soil weight was determined from a 10 -g soil sample dried for $48 \mathrm{~h}$ at $60^{\circ} \mathrm{C}$ in a drying oven.

Estimates of the activity of Rhizoctonia spp. were determined during all 4 years of study. Two different sampling strategies were employed. The first consisted of plating ten 1-cm segments from each root system onto Rhizoctonia-selective medium (RSM; $2 \%$ water agar with $1 \mu \mathrm{g} / \mathrm{ml}$ benomyl and $100 \mu \mathrm{g} / \mathrm{ml}$ chloramphenicol). After incubation at room temperature for 24 $\mathrm{h}$, the number of root segments with Rhizoctonia spp. was recorded. The second method involved estimating hyphal activity directly from the soil (23). Soils were collected from three locations within each plot to a depth of $15 \mathrm{~cm}$ ( $800 \mathrm{~g}$ of soil) using a small shovel and placed into square plastic pots ( $7 \mathrm{~cm}$ wide, $6.5 \mathrm{~cm}$ deep), each set of three pots representing one replication. The pots were watered with $30 \mathrm{ml}$ of water to bring them up to field capacity. After 2 to 3 days at room temperature, five flat toothpicks were inserted into each pot, and the pots were incubated at $15^{\circ} \mathrm{C}$ for 48 h. The five toothpicks were removed from the soils, laid onto RSM agar, incubated an addition $24 \mathrm{~h}$, and examined for the presence of Rhizoctonia spp. by using a dissecting microscope (Olympus SZ 10-40 $\mathrm{X})$. Colonies of $R$. solani and $R$. oryzae were distinguished based on hyphal morphology. The number of colonies of each species growing out from the toothpicks was estimated by using a 5-mm grid beneath the plate. If the grid square contained mycelium of $R$. solani or $R$. oryzae, it was counted as one colony, and the total number of colonies per five toothpicks was recorded. In 2002, soil was pooled from two locations within each plot and 10 toothpicks were placed in each pot.

Due to improvements in isolation efficiency and technique over the course of the study, variations in sampling procedures were made. In 2001 and 2002, the root segment assay was used, and in 2002, 2003, and 2004, the toothpick assay was employed. The 2001 and 2002 samplings coincided with times of disease assessments, whereas in 2003 and 2004, soil samples were removed every 2 weeks over the course of the growing season.

Data analysis. Field studies were arranged in a randomized complete block design with eight replications per treatment. Data for all comparisons were analyzed using the PROC GLM procedure to generate an ANOVA. Mean comparisons were made using Fisher's least significant difference (LSD) at $P=0.05$. When appropriate, transformations were selected using the Box-Cox procedure and executed prior to further analysis. All analyses were performed using SAS version 8.2 (SAS Institute Inc., Cary, NC).

\section{RESULTS}

Agronomic and yield measurements. Measurements included total number of tillers, number of crown roots, and yield. At the Pennell farm, comparison between tillage and direct seeding was made following a transition back to tillage, whereas at the Nelson farm, the comparison was made following the conversion from conventional tillage to direct seeding.

The total number of tillers per plant in conventionally tilled versus direct-seeded plots did not follow a clear trend, although in four of six comparisons for each wheat and barley, there were more tillers in tilled plots than in direct-seeded plots (Fig. 1). In the conversion from direct seeding to tillage (Pennell farm), significantly more tillers were observed in tilled plots of spring wheat in 2002 (Fig. 1A). There also was a trend toward fewer tillers on barley in the direct-seeded plots on the Nelson farm, except for the first year of the study (Fig. 1B).

In 2001, the number of crown roots was similar for crops grown with tillage or direct seeding at the Pennell farm. However, in 2002, a significant increase in the number of crown roots was associated with 
tillage on both spring wheat and spring barley (Fig. 2A). More crown roots were counted on spring wheat and spring barley plants grown with tillage at the Nelson farm early in the growing season in 2002 through 2004 (Fig. 2B); however, by 8 weeks after planting, there was no difference in the number of crown roots (30). At the Pennell farm, a significant increase in yield was measured for spring wheat grown with tillage in the first year of the transition from direct seeding to tillage (Fig. 3A). However, in 2002, the spring wheat yield at this location did not differ between tilled and direct-seeded plots. Barley yields also did not differ between tillage and direct seeding at the Pennell farm in either year of the study. At the Nelson farm, there was no difference in yields of either crop grown with tillage or direct seeding in 2001 and 2002, except for a higher yield for spring barley grown with direct seeding in 2001 (Fig. 3B). However, in 2003 and 2004, there was a significant reduction (18 to $41 \%$ ) in yield for both cereal crops when grown in direct-seeded compared with tilled plots.

Disease assessment. The incidence of Rhizoctonia root rot on crown roots was statistically similar for tilled and directseeded cereals at the Pennell farm, except for a significant reduction in disease incidence on spring wheat grown with tillage and spring barley grown with direct seeding in 2002 (Fig. 4A). In the first 2 years of the transition from tillage to direct seeding at the Nelson farm, there were few differences in the incidence of Rhizoctonia root rot on crown roots (Fig. 4B). However, in the third and fourth years, increases in disease were observed for most spring wheat and spring barley plots grown with direct seeding compared with crops grown with tillage.

Take-all was assessed on crown roots, with disease ratings recorded in 2001 and the incidence of infected seminal and crown roots recorded in 2002 to 2004. In all years of the study, the incidence of take-all was very low, with less than $2 \%$ of crown roots infected. Disease incidence also did not differ between tilled and direct-seeded plots (30).

Pythium populations and Rhizoctonia hyphal activity. Estimates of pathogen populations were determined throughout the study. Pythium populations were assessed twice in 2001 and once in 2002. At the first sampling time, populations of Pythium varied from 295 to 804 (average of 548) in 2001 and from 331 to 469 (average of 377) in 2002. By the second sampling in 2001 (8 weeks after planting), Pythium populations had declined to 154 to 327 (average of 234). However, populations of Pythium spp. did not vary substantially between soils removed from tilled versus direct-seeded plots (30).

The activity of Rhizoctonia spp. was estimated in 2001 and 2002 by plating root segments from plants, and in 2002 to 2004, by baiting soils with toothpicks and plating onto a selective medium. In 2001 and 2002, the pathogen measurements were made once about 4 weeks after planting; however, in 2003 and 2004, sampling was expanded, with estimates of populations recorded every 2 weeks throughout the growing season. $R$. oryzae was recovered consistently in numerically higher frequencies from the roots of tilled spring wheat and spring barley ( 0.8 to $6.1 \%$, average of $2.4 \%$ ) than on roots from directseeded plots ( 0.1 to 1.6 , average of $1.0 \%$ ), but the differences were not statistically different. The frequency of recovery of $R$. solani from root segments was very low and did not differ between management practices ( 0.0 to $1.6 \%$, average of $0.3 \%$ ).
Likewise, the incidence of Rhizoctonia spp. detected in 2002 by the toothpick baiting method was not significantly different between tilled and direct-seeded plots at either the Pennell or the Nelson farm. The average number of colonies per toothpick at the Pennell farm was 0.5 for $R$. oryzae and 2.7 for $R$. solani, while at the Nelson farm, the averages were 2.3 for $R$. oryzae and 0.9 for $R$. solani.

The hyphal activity of $R$. solani was substantially lower in tilled plots in both 2003 and 2004, with no colonies recovered on toothpicks from soils removed from tilled plots in one sample in 2003 and three samples in 2004 (Fig. 5). In 2003, the hyphal activity of $R$. solani in direct-seeded plots was similar to that in the tilled plots early in the growing season; however,

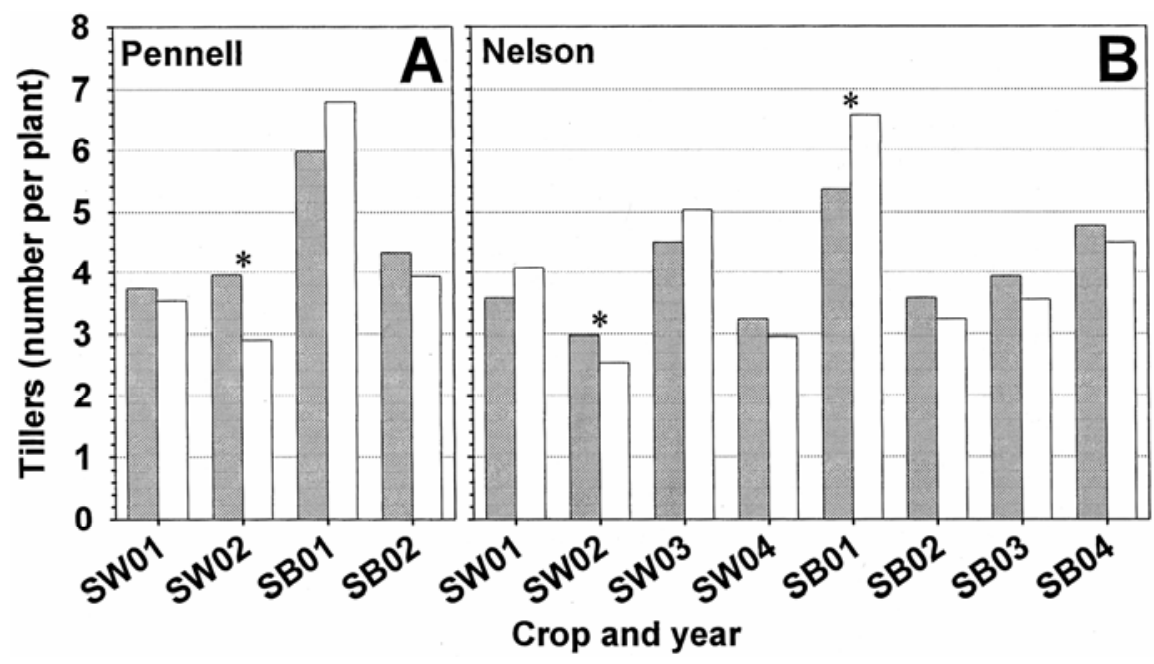

Fig. 1. Number of tillers per plant in the tillage transition study in Garfield, WA, 4 weeks after planting. $\mathrm{SW}=$ spring wheat and $\mathrm{SB}=$ spring barley with the year indicated by two numbers after the crop designation. Bars: solid, tilled; open, direct-seeded. A, Pennell farm and B, Nelson farm. Separate comparisons were made for tillage treatments within each crop and site. Values with an asterisk (*) are significantly different between tillage treatments using Fisher's LSD at $P=0.05$.

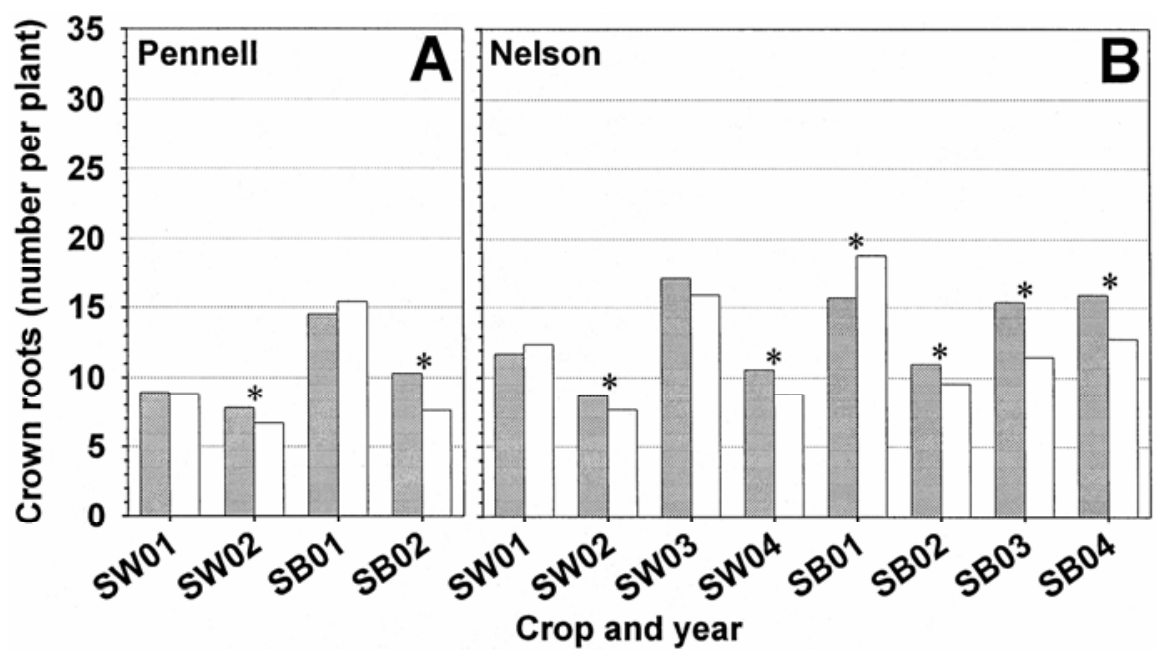

Fig. 2. Number of crown roots per plant in the tillage transition study in Garfield, WA, 4 weeks after planting. $\mathrm{SW}=$ spring wheat and $\mathrm{SB}=$ spring barley with the year indicated by two numbers after the crop designation. Bars: solid, tilled; open, direct-seeded. A, Pennell farm and B, Nelson farm. Separate comparisons were made for tillage treatments within each crop and site. Values with an asterisk $(*)$ are significantly different between tillage treatments using Fisher's LSD at $P=0.05$. 
significantly greater hyphal activity was detected from direct-seeded soils 8 to 16 weeks after planting for the spring wheat (Fig. 5A) and 8 to 14 weeks after planting for the spring barley (Fig. 5C). A similar trend was observed in 2004, with consistently more $R$. solani recovered from direct-seeded plots than from tilled plots for both spring wheat and spring barley. The hyphal activity of $R$. oryzae was found to fluctuate throughout the growing season, with similar levels of recovery in both 2003 (Fig. 6A and C) and 2004 (Fig. 6B and D). In addition, the hyphal activity of $R$. oryzae in soils did not differ between tilled versus direct-seeded spring wheat or spring barley in 2003. The same was true of spring barley in 2004; however, in the spring wheat plots, significantly more hyphal activity of $R$. oryzae was found in half of the soil samples collected from the tilled plots.

\section{DISCUSSION}

The results of this study show a major increase in Rhizoctonia root rot and a reduction in yield during the third and fourth years of the transition from conventional tillage to direct seeding. This is consistent with another study conducted in a low rainfall area (Ritzville, WA), where Rhizoctonia patches first appeared 3 years after the use of a low-disturbance directseed drill (6). Previous studies usually have shown an increase in Rhizoctonia root rot with direct seeding. However,

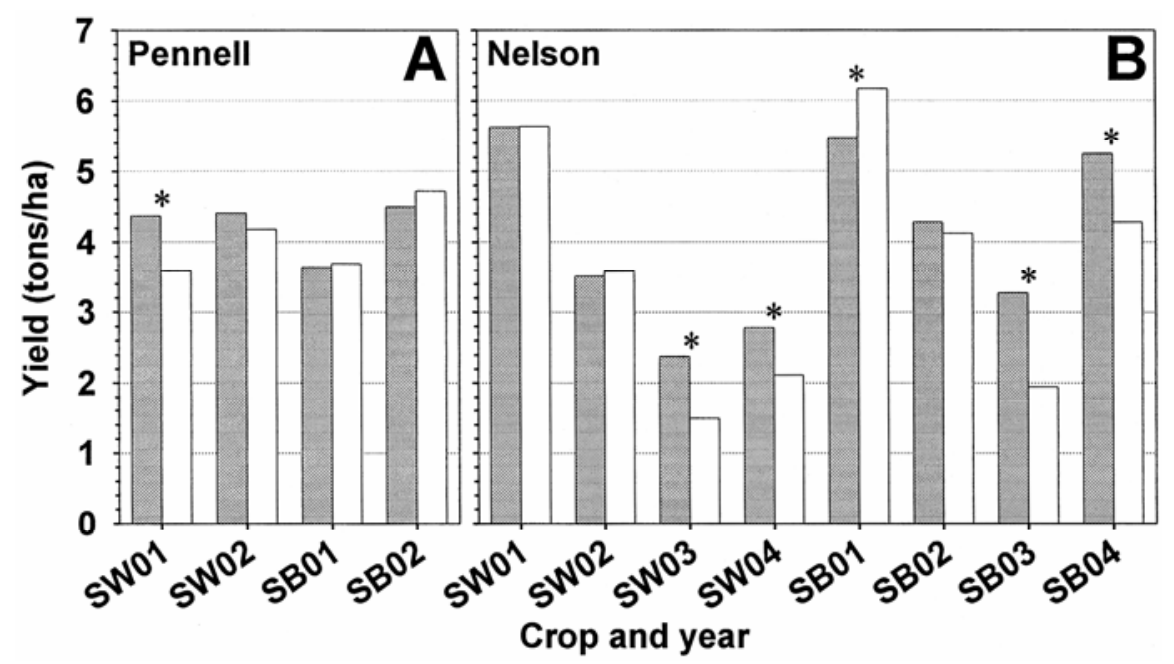

Fig. 3. Crop yield in the tillage transition study in Garfield, WA. SW = spring wheat and SB = spring barley with the year indicated by two numbers after the crop designation. Bars: solid, tilled; open, direct-seeded. A, Pennell farm and B, Nelson farm. Separate comparisons were made for tillage treatments within each crop and site. Values with an asterisk $\left(^{*}\right)$ are significantly different between tillage treatments using Fisher's LSD at $P=0.05$.

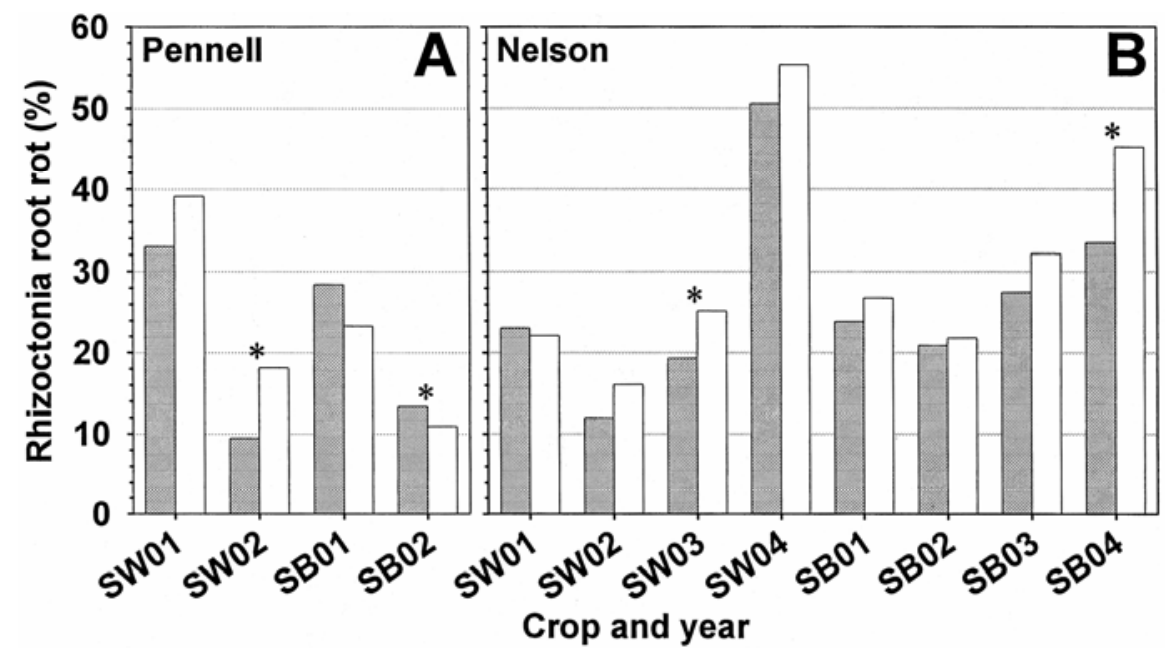

Fig. 4. Percentage of crown roots with symptoms of Rhizoctonia root rot in the tillage transition study in Garfield, WA, 4 weeks after planting. SW = spring wheat and SB = spring barley with the year indicated by two numbers after the crop designation. Bars: solid, tilled; open, direct-seeded. A, Pennell farm and $\mathbf{B}$, Nelson farm. Separate comparisons were made for tillage treatments within each crop and site. Values with an asterisk $(*)$ are significantly different between tillage treatments using Fisher's LSD at $P=0.05$. many of these studies focused on fields or plots that were in the early phases of the transition to direct seeding. MacNish (17) observed increases in Rhizoctonia root rot, but only examined the effect of direct seeding in the first 3 years of the transition to direct seeding. However, Rhizoctonia root rot did not differ between tillage variables after 25 years of a wheat-pea rotation (31).

The incidence of take-all was very low in all years of this study and population estimations of Pythium spp. indicated that the severity of Pythium root rot did not differ between tilled and direct-seeded plots. Thus, it appears that the yield reductions typically observed in the third to fifth years of direct seeding are likely due to increasing levels of Rhizoctonia root rot, with take-all and Pythium root rot having little to no impact. However, Rhizoctonia root rot and yield differences were not identified between tilled and direct-seeded plots at the Pennell farm following 12 years of continuous direct seeding. This suggests that in a long-term direct-seeded system, bringing back the plow and returning to conventional tillage does not give any increased benefit in yield or reduction in disease. Data from this farm also showed that fields managed with direct seeding for a prolonged period of time (greater than 12 years) had reduced levels of Rhizoctonia root rot, indicating a reversion back to disease levels present in conventional tillage.

A possible explanation for similar levels of Rhizoctonia in long-term direct-seeded and tilled soils is a change in the microflora of the soil. Suppression of Rhizoctonia root rot previously was documented in fields monocropped to wheat for extended periods of time (26) or in greenhouse experiments following successive plantings of wheat into soils inoculated with $R$. solani AG-8 (15). These declines in Rhizoctonia root rot may be due to enrichment for certain microorganisms and/or increases in the general suppressiveness of the soil, and similar reductions in disease may also be possible with prolonged direct seeding. Pankhurst et al. (22) found increased microbial biomass and higher populations of fungi, including cellulolytic fungi, in plots that were direct seeded for 6 or 16 years. Smiley et al. (31) reported an inverse relationship between microbial biomass and Rhizoctonia root rot incidence and severity in tilled soils managed with different crop rotations and levels of fertility. Rhizoctonia root rot also was lower when wheat was grown in soils removed from a field direct seeded for 8 years and inoculated with $R$. solani than in soils removed from a tilled field (26).

Increased soil compaction during the early years of direct seeding also may affect Rhizoctonia root rot. The drill used to seed the plots in this experiment was equipped with fluted coulters that disturb 
the soil about 3.5 to $5 \mathrm{~cm}$ below the seed. Roget et al. (27) previously demonstrated that direct-seeding drills that disturb the zone directly beneath the seed resulted in reduced Rhizoctonia root rot compared with drills that did not disturb soil. Similarly, MacNish (16) found that mixing of soils (5 to $10.5 \mathrm{~cm}$ ) reduced the level of Rhizoctonia root rot. However, subsequent compaction of the same mixed soil resulted in more disease. Although changes in the microflora may play a large role, the reason(s) for decreasing levels of Rhizoctonia root rot with prolonged direct seeding are largely unknown. Future studies to examine the impact of indigenous microorganisms, soil compaction, and changes in microclimate should help to understand this phenomenon.

In this study, the amount of take-all did not differ between plots managed with direct seeding versus tillage. Previous studies on the impact of direct seeding on take-all of wheat and barley have yielded various conclusions. In one study in Great Britain, Brooks and Dawson (3) found that the incidence of take-all was lower in direct-seeded plots on land with a history of pasture. Moore and Cook (19) demonstrated that take-all increased consistently with direct seeding at three locations within Washington, the increase being largely attributed to a substantially greater quantity of infested debris. However, when they introduced inoculum of the take-all pathogen into their plots, they saw a higher increase in disease in tilled plots, indicating that the direct-seeded plots were less conducive to disease development (19). In a recent survey of fields in eastern Washington, the level of disease did not differ between tilled and direct-seeded plots (25).

Populations of Pythium spp. monitored in 2001 and 2002 were within the range commonly reported for cereal fields in eastern Washington (7) (generally 100 to 1,000 propagules per gram of soil). The populations in our study did not differ between direct-seeded and conventionally tilled plots, regardless of the previous history of the field. Cook et al. (5) also found similar populations of Pythium spp. in tilled and direct-seeded plots. Populations of Pythium spp. in minimum tillage treatments were higher than conventional tillage at soil depths of 0 to $5 \mathrm{~cm}$, but at depths below this, populations were the same or lower than in soils with conventional tillage. This variation of pathogen distribution is likely a reflection of where the plant residues are found, since in the direct-seeded or minimum tilled plots, residues are located near the surface. One limitation of these dilution plate studies is the inability to distinguish among the many Pythium spp., and there may be a shift in species composition due to a change in management practices.

Based on the populations of Rhizoctonia spp. recovered from toothpick baiting of soils, it appears that the increased Rhizoctonia root rot in the direct-seeded plots at the Nelson farm is due primarily to $R$. solani. Tillage previously was demonstrated to be an effective means of controlling Rhizoctonia root rot (17). However, $R$. oryzae was generally unaffected by tillage and may be equally problematic in tilled and direct-seed systems. Survival mechanisms for $R$. solani and $R$. oryzae may explain the difference in hyphal activity with tillage for these two pathogens. $R$. solani relies predominately on plant roots or debris for survival throughout and between growing seasons, existing as either monilioid cells or thick-walled brown hyphae (20), but rarely forming sclerotia (34). In contrast, $R$. oryzae has two advantages when colonizing a new substrate. First, $R$. oryzae can readily form microsclerotia and can become dormant when conditions are unfavorable for growth. Numerous microsclerotia form on agar media under laboratory conditions within about 1 week. $R$. oryzae also is less reliant on plant debris for survival, and the number of microsclerotia within a given volume of soil likely outnumbers the number of plant particles available for colonization. Second, the radial growth rate of $R$. oryzae is much greater than that of $R$. solani in agar medium, which may enable $R$. oryzae to rapidly colonize a new substrate when favorable conditions return.

No clear trend was evident when looking at the agronomic measurements with the exception of the number of crown roots per plant. A substantial reduction in the number of crown roots was seen when transitioning to direct seeding (Nelson farm). However, differences in the number of crown roots in the conversion to tillage (Pennell farm) were less evident, and by mid-July, there was no difference between tilled and direct-seeded plots (30). Rhizoctonia root rot likely played a role in reducing plant vigor early in the growing season at some locations, and was previously implicated in delayed maturation of wheat (36). Changes to the soil environment with direct seeding also may have an important role. Smiley and Wilkins (33) reported a 2to 3-week delay in maturity of barley within direct-seeded plots. This delayed plant development could be due to cooler soil temperatures associated with direct seeding early in the growing season. Crop residues remaining in the field reduce soil temperatures by shading the soil surface and reflecting light. This layer of debris also traps water, thereby increasing the soil moisture when compared to tillage. These factors combined could impact the growth rate of seedlings in the spring.

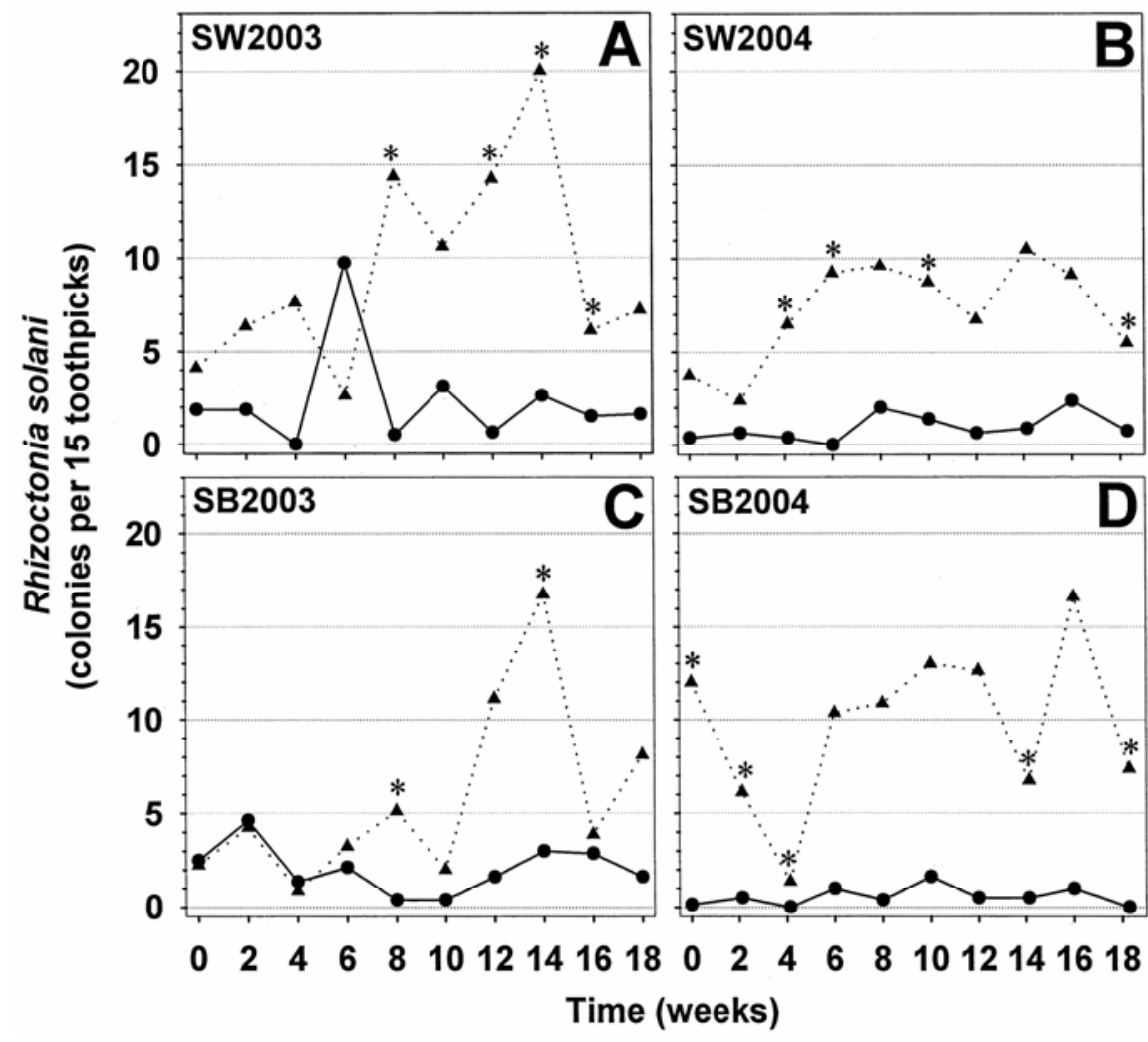

Fig. 5. Toothpick colonization by Rhizoctonia solani from soils at the Nelson farm in Garfield, WA. A, Cropped to spring wheat in 2003; B, cropped to spring wheat in 2004; C, cropped to spring barley in 2003; and D, cropped to spring barley in 2004. Conventionally tilled plots, $\boldsymbol{\Delta}$, direct-seeded plots. Three soil subsamples were removed from each plot and placed in separate pots, and five toothpicks were placed in each pot. Each set of three pots represents one replicate. Values represent the total number of colonies recovered per plot. Points with an asterisk $\left(^{*}\right)$ are significantly different between tillage treatments using Fisher's LSD as $P=0.05$. 


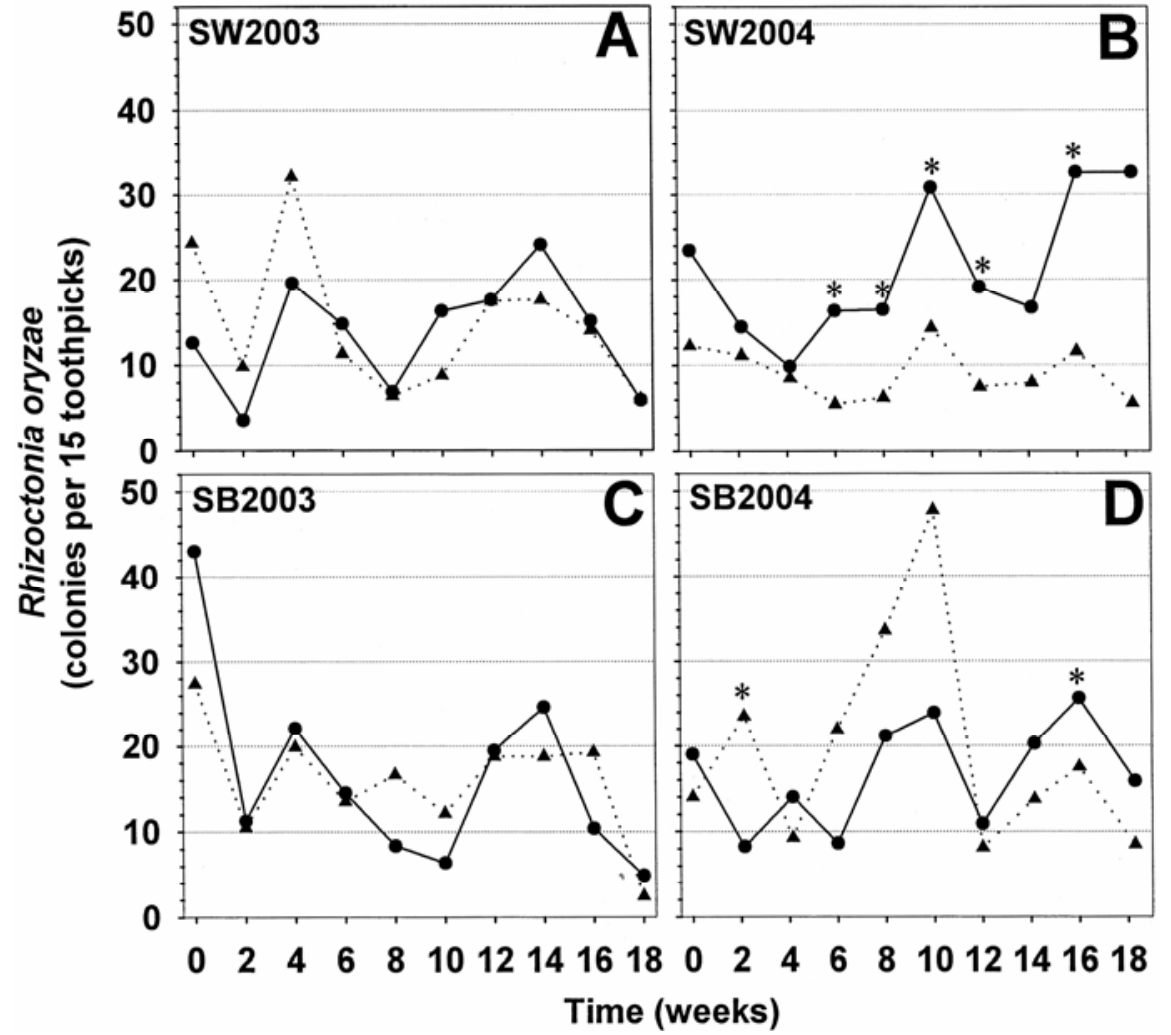

Fig. 6. Toothpick colonization by Rhizoctonia oryzae from soils at the Nelson farm in Garfield, WA. A, Cropped to spring wheat in 2003; B, cropped to spring wheat in 2004; C, cropped to spring barley in 2003; and D, cropped to spring barley in 2004. $\boldsymbol{Q}$, Conventionally tilled plots, $\boldsymbol{\Delta}$, direct-seeded plots. Three soil subsamples were removed from each plot and placed in separate pots, and five toothpicks were placed in each pot. Each set of three pots represents one replicate. Values represent the total number of colonies recovered per plot. Points with an asterisk (*) are significantly different between tillage treatments using Fisher's LSD as $P=0.05$.

The data presented above indicate that Rhizoctonia root rot will be a problem primarily in the transition to direct seeding in the early years of the conversion. During these years, it is extremely important to control volunteer plants and grassy weeds in direct-seeded fields between crops to reduce populations of Rhizoctonia spp. and minimize the impact of this disease on the subsequent crop (32). In this study, the population of $R$. solani was found to be substantially lowered by tillage; however, populations of $R$. oryzae were unaffected or increased with tillage. In addition, $R$. oryzae previously was shown to have a fairly broad host range (10). Thus, managing volunteers prior to planting also may be important for farmers who conduct conventional tillage. Management practices for take-all and Pythium root rot will not differ from those used with conventional tillage. The primary control measures for these two diseases involve the use of rotation for control of take-all $(4,14)$ and planting into well-drained soils using new, fungicide-treated seed for control of Pythium root rot $(5,9)$.

Many questions still exist in relation to understanding the effect of direct seeding on root diseases of wheat and barley. In addition, the population dynamics of individual Rhizoctonia and Pythium species are largely unknown. Further work should examine the role of soil microflora in this transition. Continued research on the impact of direct seeding and the changes in soil will lead to a better understanding of these root pathogens as well as new methods for disease management and control.

\section{LITERATURE CITED}

1. Bailey, K. L., and Duczek, L. J. 1996. Managing cereal diseases under reduced tillage. Plant Pathol. 18:159-167.

2. Bailey, K. L., Mortensen, K., and Lafond, G. P. 1992. Effects of tillage systems and crop rotations on root and foliar diseases of wheat, flax, and peas in Saskatchewan. Can. J. Plant Sci. 72:583-591.

3. Brooks, D. H., and Dawson, M. G. 1968. Influence of direct-drilling of winter wheat on incidence of take-all and eyespot. Ann. Appl. Biol. 61:57-64.

4. Cook, R. J. 1981. The influence of rotation crops on take-all decline phenomenon. Phytopathology 71:189-192.

5. Cook, R. J., Chamswarng, C., and Tang, W.-H. 1990. Influence of wheat chaff and tillage on Pythium populations in soil and Pythium damage to wheat. Soil Biol. Biochem. 7:939-947.

6. Cook, R. J., Schillinger, W. F., and Christensen, N. W. 2002. Rhizoctonia root rot and takeall of wheat in diverse direct-seed spring cropping systems. Can. J. Plant Pathol. 24:349-358.

7. Cook, R. J., Sitton, J. W., and Haglund, W. A. 1987. Influence of soil treatments on growth and yield of wheat and implications for control of Pythium root rot. Phytopathology 77:11921198.
8. Cook, R. J., Sitton, J. W., and Waldher, J. T. 1980. Evidence for Pythium as a pathogen of direct-drilled wheat in the Pacific Northwest. Plant Dis. 64:102-103.

9. Cook, R. J., and Veseth, R. J. 1991. Wheat Health Management. American Phytopathological Society, St. Paul, MN.

10. Davis, R. 2005. Factors affecting occurrence and severity of Rhizoctonia root rot and Fusarium crown rot in direct-seeded cereals. M.S. thesis. Washington State University, Pullman.

11. Doran, J. W. 1980. Soil microbial and biochemical changes associated with reduced tillage. Soil Sci. Soc. Am. J. 44:765-771.

12. Doran, J. W. 1987. Microbial biomass and mineralizable nitrogen distributions in notillage and plowed soils. Biol. Fertil. Soils 5:68-75.

13. Follett, R. F., and Schimel, D. S. 1989. Effect of tillage practices on microbial biomass dynamics. Soil Sci. Soc. Am. J. 53:1091-1096.

14. Gardner, P. A., Angus, J. F., Pitson, G. D., and Wong, P. T. W. 1998. A comparison of six methods to control take-all in wheat. Aust. J. Exp. Agric. 49:1225-1240.

15. Lucas, P., Smiley, R. W., and Collins, H. P. 1993. Decline of Rhizoctonia root rot on wheat in soils infested with Rhizoctonia solani AG-8. Phytopathology 83:260-265.

16. MacNish, G. C. 1984. The use of undisturbed soil cores to study methods of controlling rhizoctonia patch of cereals. Plant Pathol. 33:355-359.

17. MacNish, G. C. 1985. Methods of reducing rhizoctonia patch of cereals in Western Australia. Plant Pathol. 34:175-181.

18. Mircetich, S. M., and Kraft, J. M. 1973. Efficiency of various selective media in determining Pythium population in soil. Mycopathol. Mycol. Appl. 50:151-161.

19. Moore, K. J., and Cook, R. J. 1984. Increased take-all of wheat with direct drilling in the Pacific Northwest. Phytopathology 74:10441049.

20. Neate, S. M. 1987. Plant debris in soil as a source of inoculum of Rhizoctonia in wheat. Trans. Br. Mycol. Soc. 88:157-162.

21. Pankhurst, C. E., McDonald, H. J., and Hawke, B. G. 1995. Influence of tillage and crop rotation on the epidemiology of Pythium infections on wheat in a red-brown earth of South Australia. Soil Biol. Biochem. 27:1065-1073.

22. Pankhurst, C. E., McDonald, H. J., Hawke, B. G., and Kirkby, C. A. 2002. Effect of tillage and stubble management on chemical and microbiological properties and the development of suppression towards cereal root disease in soils from two sites in NSW, Australia. Soil Biol. Biochem. 34:833-840.

23. Paulitz. T. C., and Schroeder, K. L. 2005. A new method for the quantification of Rhizoctonia solani and $R$. oryzae from soil. Plant Dis. 89:767-772.

24. Pumphrey, F. V., Wilkins, D. E., Hane, D. C., and Smiley, R. W. 1987. Influence of tillage and nitrogen fertilizer on Rhizoctonia root rot (bare patch) of winter wheat. Plant Dis. 71:125-127.

25. Ramsey, N. E. 2001. Occurrence of take-all on wheat in Pacific Northwest cropping systems. M.S. thesis. Washington State University, Pullman.

26. Roget, D. K. 1995. Decline in root rot (Rhizoctonia solani AG-8) in wheat in a tillage and rotation experiment at Avon, South Australia. Aust. J. Exp. Agric. 35:1009-1013.

27. Roget, D. K., Neate, S. M., and Rovira, A. D. 1996. Effect of sowing point design and tillage practice on the incidence of rhizoctonia root rot, take-all and cereal cyst nematode in wheat and barley. Aust. J. Exp. Agric. 36:683-693.

28. Rovira, A. D. 1986. Influence of crop rotation 
and tillage on Rhizoctonia bare patch of wheat. Phytopathology 76:669-673.

29. Schillinger, W. F., Cook, R. J., and Papendick, R. I. 1999. Increased dryland cropping intensity with no-till barley. Agron. J. 91:744-752.

30. Schroeder, K. L. 2004. The dynamics of root diseases of wheat and barley in the transition from conventional tillage to direct seeding. Ph.D. diss. Washington State University, Pullman.

31. Smiley, R. W., Collins, H. P., and Rasmussen,
P. E. 1996. Diseases of wheat in long-term agronomic experiments at Pendleton, Oregon. Plant Dis. 80:813-820.

32. Smiley, R. W., Ogg, A. G., Jr., and Cook, R. J. 1992. Influence of glyphosate on Rhizoctonia root rot, growth, and yield of barley. Plant Dis. 76:937-942.

33. Smiley, R. W., and Wilkins, D. E. 1993. Annual spring barley growth, yield, and root rot in high- and low-residue tillage systems. J. Prod. Agric. 6:270-275.
34. Warcup, J. H., and Talbot, P. H. B. 1962. Ecology and identity of mycelia isolated from soil Trans. Br. Mycol. Soc. 45:495-518.

35. Weller, D. M., Cook, R. J., MacNish, G. Bassett, E. N., Powelson, R. L., and Petersen, R. R. 1986. Rhizoctonia root rot of small grains favored by reduced tillage in the Pacific Northwest. Plant Dis. 70:70-73.

36. Wiese, M. V. 1987. Compendium of Wheat Diseases. 2nd ed. American Phytopathological Society, St. Paul, MN 